УДК 784:78.071 (477) «19/20»

\author{
Мустафаєв Фемій Мансурович, \\ професор кафедри академічного \\ і естрадного вокалу та звукорежисури \\ Національної академії керівних \\ кадрів культури і мистецтв, \\ Народний артист України \\ kev@ dakkkim.edu.ua \\ ORCID 0000-0001-5412-8702
}

\title{
ІСТОРИЧНІ АСПЕКТИ РОЗВИТКУ УКРАЇНСЬКОЇ ВОКАЛЬНО-ПЕДАГОГІЧНОЇ ШКОЛИ У ХХ - НА ПОЧАТКУ ХХІ СТОЛІТТЯ
}

\begin{abstract}
Мета роботи. У дослідженні виділено та охарактеризовано основні етапи розвитку національної вокально-педагогічної школи у контексті соціокультурних процесів XX - початку XXI ст., що відбувалися в українському суспільстві. Методологія дослідження базується на застосуванні історико-культурного, системного та аналітичного методів, що дало можливість розглянути історію української вокально-педагогічної школи у іiі взаємозв'язках із соціокультурними процесам XX - початку XXI ст. Наукова новизна роботи полягає в тому, що в українській науці вперше було висвітлено діяльність національної вокально-педагогічної школи у синкретизмі мистецько-художнього та соціокультурного чинників, які протягом ХХ ст. й сьогодні функціонують у нерозривній єдності. Висновки. Українська вокально-педагогічна школа у ХХ ст. пройшла три етапи свого розвитку, кожен з яких тривав третину століття, у XXI ст. розпочався іiі четвертий етап. Перший етап ознаменовано створенням засад національної вокально-педагогічної школи на основі академічного співу у поєднанні з українськими вокально-співочими традиціями. Для другого етапу характерні стагнаційні тенденції, пов'язані з іiі відірваністю від загальносвітових процесів розвитку вокального виконавства. Третій етап характеризується плюралістичністю трактування вокально-педагогічної школи, яка відтепер включає не лише академічний, а й інші види співу, актуальні у світовому культурному просторі. Четвертий етап ще не закінчено, для нього характерно продовження основних тенденцій попереднього. У співвідношенні до аналогічного періоду ХX ст. він відрізняється більшою динамікою і на новому історичному витку повторює його культуротворчий сплеск, який заклав підвалини української вокально-педагогічної школи.
\end{abstract}

Ключові слова: українське вокальне мистецтво, вокально-педагогічні школи, соціокультурні процеси в Україні, історична типологія.

Мустафаев Фемий Мансурович, профессор кафедры академического и эстрадного вокала и звукорежиссуры Национальной академии руководящих кадров культуры и искусств, Народный артист Украиньл XXI века

Исторические аспекты развития украинской вокально-педагогической школы в ХХ - в начале

Цель работы. В исследовании выделены и охарактеризованы основные этапы развития национальной вокально-педагогической школы в контексте социокультурных процессов XX - начала XXI в., происходивших в украинском обществе. Методология исследования базируется на применении историко-культурного, системного и аналитического методов, что позволило рассмотреть историю украинской вокальнопедагогической школы в ее взаимосвязях с социокультурными процессам XX - начала XXI в. Научная новизна работы заключается в том, что в украинской науке впервые отражена деятельность национальной вокально-педагогической школы в синкретизме художественно-художественного и социокультурного факторов, которые на протяжении ХХ в. и сегодня функционируют в неразрывном единстве. Выводы. Украинская вокально-педагогическая школа в XX в. прошла три этапа своего развития, каждый из которых длился треть века, в XXI в. начался ее четвертый этап. Первый этап ознаменован созданием фундамента национальной вокально-педагогической школы на основе академического пения в сочетании с украинскими вокально-певческими традициями. Для второго этапа характерны стагнационные тенденции, связанные с ее оторванностью от общемировых процессов развития вокального исполнительства. Третий этап характеризуется плюралистичностью трактовки вокально-педагогической школы, которая отныне включает не только академический, но и другие виды пения, актуальные в мировом культурном пространстве. Четвертый этап еще не закончен, для него характерно продолжение основных тенденций предыдущего. В соотношении с аналогичным периодом XX в. он отличается большей динамикой и на новом историческом витке повторяет его культуротворческий всплеск, который заложил основы украинской вокально-педагогической школы.

Ключевые слова: украинское вокальное искусство, вокально-педагогические школы, социокультурные процессы в Украине, историческая типология.

(C) Мустафаєв Ф. М., 2019 
Mustafayev Femiy, People's Artist of Ukraine, Professor of the Department of Academic and Variety Vocal and Sound Directing, National Academy of Culture and Arts Management, centuries

Historical Aspects of the Development of the Ukrainian Vocal Pedagogical School in the $20^{\text {th }}-e$ arly $^{2} 1^{\text {st }}$

Purpose of Article. The purpose of the research are to identify and characterize the main stages of the development of the national vocal pedagogical school in the context of the sociocultural processes of the $20^{\text {th }}-$ early $21^{\text {st }}$ centuries that took place in Ukrainian society. Methodology. The research methodology is based on the application of historical cultural, systematic and analytical methods, which have allowed us to consider the history of the Ukrainian vocal pedagogical school in its interconnections with the sociocultural processes of the $20^{\text {th }}-$ early $21^{\text {st }}$ centuries. Scientific Novelty. The scientific novelty of the article is the fact that for the first time Ukrainian science reflects the activities of the national vocal pedagogical school in the syncretism of artistic and sociocultural factors, which have been acting in the inextricable unity throughout the $20^{\text {th }}$ century and $21^{\text {st }}$ century. Conclusions. In the $20^{\text {th }}$ century the Ukrainian vocal pedagogical school went through three stages of its development, each of which lasted a third of a century, in the $21^{\text {st }}$ century its fourth stage began. The first stage was marked by the foundation of a national vocal pedagogical school, based on academic singing in combination with Ukrainian vocal traditions. The second stage is characterized by stagnant trends, associated with its isolation from global processes of vocal performance development. The third stage is characterized by a pluralistic interpretation of the vocal pedagogical school, which includes academic as well as other types of singing today that are relevant in the world cultural space. The fourth stage has not finished yet; it is characterized by the continuation of the main trends of the previous ones. Regarding to the same period of the $20^{\text {th }}$ century, it is more dynamic. At the new historical stage it repeats its cultural outburst, which is the foundation of the Ukrainian vocal pedagogical school. typology.

Key words: Ukrainian vocal art, vocal pedagogical schools, sociocultural processes in Ukraine, historical

Актуальність теми. Українська вокально-педагогічна школа налічує вже більше ста років, иї здобутки відомі у всьому світі завдяки блискучим виступам українських виконавців на оперних сценах театрів у всьому світі. Сьогодні в Україні $є$ кілька регіональним осередків, які формують єдину національну школу, їх становлення і розвиток був тісно пов'язаний з відкриттям та роботою консерваторій (нині - музичних академій), в стінах яких готувалися і нині готуються артистивокалісти для філармоній та оперних театрів. Повна історія української вокальної школи у іï виконавському та педагогічному вимірах ще не написана, для цього потрібно не одне покоління дослідників, які б зібрали не лише фактологічний матеріал, а й осмислили цей феномен в широкому історико-культурному контексті. Проте варто розпочати цю роботу, сконцентрувавшись на історикокультурологічній інтерпретації основних етапів розвитку національної вокально-педагогічної школи, яка у XX ст. пережила не лише злети, а й важкі часи, пов'язані з непростою історією нашої держави.

Аналіз останніх досліджень і публікацій. Сьогодні спостерігається посилення інтересу до національної вокально-педагогічної школи як культурно-мистецького феномену. Вже зібрано багатий фактологічний матеріал з історії української вокальної школи, починаючи від початку ХХ ст. до сьогодні. В основному він зосереджений в узагальнюючих працях, виданих у зв'язку з ювілейними датами осередків підготовки академічних вокалістів, серед яких виділимо видання, присвячені музичним академіям Києва [4], Харкова [8], Одеси [5], Дніпра [3]. У цих книгах висвітлено історію вокальних класів головних регіональних осередків України, подано біографії найбільш видатних вокалістів та їх учнів. Відзначимо, що вокальні школи є не лише на регіональному, а й локальному рівні, але вони розглядаються зазвичай у місцевих виданнях, присвячених історії культури того чи іншого регіону. Серед праць, завданням яких став розгляд української вокально-педагогічної школи як культурно-мистецького феномену, виділимо дві, а саме монографії В. Антонюк «Українська вокальна школа: етнокультурологічний аспект» (1999) [1] та підручника Б. Гнидя «Історія вокального мистецтва» (1997) [2]. Остання праця, хоча і має статус підручника, розглядає українську вокальну школу як феномен у їі зв'язках із зарубіжними. Культурологічну спрямованість має праця В. Антонюк, в якій уперше осмислюється національна професійна школа сольного співу, їі генеза, тенденції розвитку та перспективи в контексті міжетнічного діалогу культур. Ці праці й сьогодні не втратили своєї цінності, проте час рухається уперед, і сьогодні необхідно шукати нові підходи осмислення історії української вокально-педагогічної школи у світлі нових історичних і культурних викликів. У рамках однієї статті важко охопити усі аспекти розвитку професійної вокальної освіти у ii розмаїтті, тому зосередимося на історії київської вокально-педагогічної школи, виділивши іï основні етапи розвитку.

Мета статті - виділення та характеристика основних етапів розвитку національної вокальнопедагогічної школи у контексті соціокультурних процесів XX - початку XXI ст., що відбувалися в українському суспільстві. 
Виклад основного матеріалу. Методологічними засадами нашого дослідження мають стати розробки, які б розглядали історію національного музичного мистецтва в контексті соціокультурних явищ, які відбувалися в суспільстві. Серед сучасних мистецтвознавців цікаву періодизацію історикокультурних процесів у музичному мистецтві запропонувала М. Ржевською у низці своїх статей [6; 7]. Дослідниця трактує кожен період музично-культурного процесу як такий, що якісно відрізняється як від попереднього, так і наступного, він є «полем реалізації у часі певної культурної парадигми, динамічним втіленням конкретної моделі культури» [7,98]. М. Ржевська пропонує музичнокультурний процес України XX ст. розглядати як чергування активного та пасивного станів культури. Кожен 3 цих етапів займає приблизно третину століття, де перший ознаменований культурним злетом й формуванням підвалин національної культури, другий відзначений гальмуванням національних культуротворчих процесів, певним застоєм та протиставленні офіційної і неофіційної культури. Третій період не є повними поверненням до першого, він поєднує риси активного та пасивного станів культури. Дослідниця віддає перевагу історико-культурним процесам, що відбувалися на Наддніпрянщині, вважаючи їх головним річищем розвитку української культури [6, 68]. Також М. Ржевська при характеристиці кожного 3 періодів зауважує, що кожен 3 них відзначається плавністю переходів, вони не мають чітко визначеної межі, і в перехідні моменти поступово актуалізуються риси, що надалі стануть центральними [7, 99].

Відзначимо концептуальність засад періодизації М. Ржевської, що дозволяє цілісно охарактеризувати культурно-мистецькі процеси в Україні у XX ст., проте зауважимо три моменти. По-перше, подібні соціокультурні процеси відбувалися на лише в Україні, а на усіх теренах СРСР. По-друге, сьогодні вже минула якщо не уся друга третина XXI ст., то принаймні його більша половина. Якщо рухатися далі за цією логікою, то наразі має бути культурна стагнація, чого ми не бачимо. По-третє, ця періодизація була запропонована для композиторської творчості, яка не завжди тотожна виконавській та педагогічній. Отже, згадана історична цілком відповідає культурній моделі XX ст., однак потребує коригування відповідно до реалій XXI ст.

В науковій літературі історію української вокально-педагогічної школи справедливо пов'язують 3 діяльністю музично-драматичної школи М. Лисенка, відкриту у 1904 р. До цього часу у місті працювали багато інших приватних шкіл, де навчали співу, проте жодна 3 них не ставила на меті створення національної співацької школи. Як справедливо зазначає В. Антонюк, реорганізована у 1918 р. в Музично-драматичний інститут імені М. Лисенка і приєднавшись у 1928 р. до Київської консерваторії, навчальний заклад, створений М. Лисенком, став творчо-педагогічною лабораторією української вокальної школи, яка з кожним роком набувала національно специфічних рис [1, 57].

У школі М. Лисенка викладали спів М. Зотова, К. Конча, О. Мишуга, О. Муравйова. Важливим аспектом було перенесення традицій італійської школи співу на український грунт. Заради формування української національної школи О. Мишуга відмовився від вигідного контракту і став викладачем у закладі М. Лисенка, де пропрацював близько шести років. Важливо, що він викладав українською мовою, а у своїй роботі прагнув базуватися на національному підгрунті. Фактично О. Мишугу можна вважати творцем національної української вокальної школи. Важливо, що національна українська школа співу була сформована не на засадах емпіризму та «таємничості», а базувалася на твердій науковій основі, де центральною ідеєю стало положення, що спів $\epsilon$ продовженою мовою. Його учні М. Микиша та М. Донець-Тессейр перенесли його методику викладання до Київської консерваторії, передавши традиції наступним поколінням.

О. Муравйова як викладачка музично-драматичної школи М. Лисенка, а пізніше Київської консерваторії, також стояла у витоків української вокально-педагогічної школи. Окрім суто вокальних новацій, вона приділяла особливу увагу індивідуальності кожного учня, намагалася, щоб іiі учні органічно поєднували вокально-технічну майстерність з художнім образом. Завдяки іiі художній інтуїції О. Муравйова могла працювати як викладач з різними голосами. Серед їі учнів - 3. Гайдай, I. Козловський, М. Литвиненко-Вольгемут, Л. Руденко та ін.

О. Мишуга та О. Муравйова заклали підвалини української вокально-педагогічної школи в іiі академічному варіанті, базуючись на засадах італійської вокальної традиції. Однак говорити про національні традиції викладання вокалу недостатньо без врахування народнопісенної творчості, особливо в їі композиторських обробках. М. Лисенко та його послідовники у своій композиторській діяльності часто зверталися до обробок народних пісень, тож важливо було не лише передати в музиці особливості фольклору, але й у вокалі показати специфіку народних пісень. Якщо сьогодні академічний і фольклорний спів (останній завдяки його автентичним формам) є різними формами вокалу, що мають свої специфічні риси, то на першому етапі розвитку національної вокальної школи ïх не розмежовували. Тому цілком слушними виглядають поради М. Леонтовича у його практичному 
курсі навчання співу, коли він радив ставити голос на основі народних мелодій, а ладовий слух мав формуватися на конкретних мелодичних прикладах. Пізніше цю традицію продовжували у дитячий студії хору імені Г. Верьовки, де академічна постановка голосу виховувалася на матеріалі народних пісень [1, 101-102]. Народна пісня у вокальному плані є більш простою, ніж класична арія чи солоспів, більш зручна та природна для голосу, тому іiі доцільно використовувати як навчальний матеріал. У процесі постановки академічного вокалу, особливо при виконанні обробок, зроблених композиторами-класиками, народна пісня стає тим самим благодатним матеріалом, який гармонічно поєднує два різні типи співу - академічний i народний, а, отже, сполучає традиції світову й національну вокальні школи.

Отже, на першому етапі становлення української вокально-педагогічної школи (перша третина XX ст.), відбувається ii становлення на основі італійської вокальної школи та наукових методах викладання співу, які були тісно пов'язані з національними вокально-співочими традиціями, що базувалися на фольклорі. Тому цілком справедливо можна казати про першу третину XX ст. як формування й злет української вокально-педагогічної школи, яка стала невід'ємною складовою національної культури.

Другий етап розвитку українською культури є найбільш складним. На цей час припадають і репресії кінця 1930-х рр., і Друга світова війна, і повоєнні сталінські «чистки». Українізація, а, отже, розвиток виконавських шкіл на засадах національного мистецтва, було припинено або загальмовано $\mathrm{i}$ відновлено лише у 1960-х рр. Переслідування видатних митців не обійшло й головний музичний осередок країни - Київську консерваторію. Найтрагічнішими були 1948-1949 рр., коли партія звинуватила викладачів консерваторії у космополітизмі й формалізмі, а також ізольованості науки від потреб викладачів і студентів. Унаслідок цього було звільнено низку викладачів, у тому числі 3 кафедри оперної підготовки та сольного співу. На кафедрі сольного співу унаслідок кадрових «чисток» кілька років поспіль бракувало вісім штатних одиниць [4, 195-196]. Однак попри складні часи, у цей період у Київській консерваторії вокальна школа продовжувала розвиватися. У навчальному закладі працювали видатні викладачі-вокалісти, серед яких Д. Свтушенко, М. ДонецьТессейр, О. Брагін, Е. Скрипчинська та багато інших прекрасних педагогів, які виховували оперних та камерних вокалістів, які працювали на українській сцені.

Також у цей період розвиток національної вокальної школи не був спрямований на охоплення усіх можливих напрямів виконавства. Українська вокально-педагогічна школи була відзначена певним консерватизмом. Наприклад,у цей час не йшлося про вокал XX ст., який сформувався на основі авангардних течій першої третини XX ст. У попередні роки він також не був центральним в українській виконавській практиці, i, відповідно, не міг бути широко представлений у навчальному репертуарі. Проте саме у другій третині XX ст. про вокальний авангард взагалі не йшлося. Натомість українська вокальна школа у їі спрямованості на традиційне бельканто у поєднання з елементами народнопісенної традиції здійснила значний вплив на тогочасну естраду, на якій у 1950-х рр. виступали оперні співаки Д. Гнатюк, К. Огнєвий, А. Мокренко, Д. Петриненко, Ю. Богатіков, Ю. Гуляєв, виконуючи пісні П. Майбороди, О. Білаша, І. Шамо, Б. Буєвського та ін.

Обмеженість полягала і у відсутності зв'язків із-за кордоном, де у цей час не лише йшли процеси збереження у нових реаліях XX ст. традицій класичного академічного виконавства, а й відбувалися пошуки у вокальному мистецтві на основі нових засобів і прийомів, знайдених в естрадному, старовинному, авангардному, фольклорному вокалі. На жаль, у той період українська вокально-педагогічна школа відповідно до соціокультурної ситуації у країні розвивалася поза світовим контекстом.

Таким чином, друга третина XX ст. у розвитку національної вокально-педагогічної школи відзначена стагнаційними процесами, що пояснювалося iї відірваністю від загальносвітових процесів. При цьому було збережено іiі національне коріння та академізм як базові ознаки, що були сформовані у попередній період.

Неоднорідністю соціокультурних процесів відзначена остання третина ХХ ст. На цей період припадає й хрущовська відлига, брежнєвський застій, горбачовська перебудова i отримання Україною незалежності. Відповідно до цих подій остання третина ХX ст. знаменується різновекторністю розвитку, поєднуючи риси активного та пасивного станів культури (за М. Ржевською) 3 превалюванням рис першого. Цей період ознаменований плюралістичністю мистецьких стилів, пов'язаний 3 постмодерним мисленням, що знайшло відображення й в українському вокальному мистецтві, попри те, що більшу частину цього періоду Україна у складі СРСР знаходилася за «залізною завісою». 
У цей час продовжує активно розвиватися класична академічна вокальна школа. Серед викладачів Київської консерваторії - Є. Чавдар, К. Огнєвой, М. Кондратюк, Л. Руденко, Є. Мірошниченко, Д. Петриненко, В. Третяк, Г. Туфтіна, А. Мокренко, М. Стеф'юк, З. Христич, В. Буймістер та ін. Усі вони у свій час були знаними виконавцями, що отримали знання народних артистів, і перейшли на викладацьку роботу для передачі свого артистичного досвіду молодому поколінню, одночасно продовжуючи педагогічні традиції, закладені своїми попередниками. Випускники Київської консерваторії у цей період плідно працюють на сценах Української РСР і СРСР, а після відновлення незалежності - у країнах Європи та світу. Таким чином можна говорити про збереження та одночасне оновлення української вокальної академічної школи у ії̈ національній основі.

Також у цей період йдуть процеси осучаснення поняття вокалу як напряму музичного мистецтва. Академічного вокалу вже недостатньо для повноцінного функціонування вокальної школи, тому сьогодні поступово йде включення у поняття вокально-педагогічної школи інших напрямів вокалу - естрадного, народного (автентичного), а також з кінця ХХ ст. й старовинного. Академічний вокал також не $є$ однорідним і включає як класико-романтичний, так і сучасний (авангардний). Усі ці напрями представлені в українському культурному просторі останньої третини $\mathrm{XX}$ ст. неоднаково. Найбільш активно розвивається класико-романтична традиція, яка є базовою для національної вокально-педагогічної школи й сьогодні. Народний вокал також посідає значне місце в українській вокальній школі, проте автентичний вокал має менш тривалу історію - лише 3 1980-х рр. Естрадний спів як напрям, що $є$ відмінним від академічного, у концертній практиці був представлений з 1970-х рр., проте вивчення естрадного співу в навчальних закладах розпочалося лише з 1990-х рp. I досі йдуть серед педагогів-вокалістів суперечки щодо можливості та доцільності виховання естрадних виконавців на традиціях академічної вокальної школи. Стосовно ж старовинного вокалу можна відзначити, що у цей період відбулося лише перше знайомство українських виконавців з цим напрямом.

Таким чином щодо розвитку української вокально-педагогічної школи останньої третини $\mathrm{XX}$ ст. можна сказати, що у цей період відбувається розширення змісту цього поняття. При цьому базовим залишається академічний спів, який доповнюється не лише народним, а й новими напрямками вокалу, актуальними у світовій практиці. У соціокультурному плані період останньої третини XX ст. у розвитку української вокально-педагогічної школи можна визначити як активний, хоча й неоднорідний упродовж усієї його тривалості.

Сьогоднішній етап розвитку української вокальної школи у культуротворчому відношенні також $є$ активним. Він $є$ продовженням попереднього, але одночасно таким, що розширює його горизонти. I сьогодні центром української вокально-педагогічної школи $є$ Київ, який зберігає i одночасно оновлює традиції, що складалися протягом попередніх ста років. Сьогодні в Національній музичній академії України ім. П. І. Чайковського працюють дві вокальні кафедри - сольного співу (завідувач - Народний артист України, професор О. Дяченко) та камерного співу (завідувачка заслужена артистка України, доктор культурології, професор В. Антонюк), які готують академічних співаків, що після закінчення стають гордістю української та світової сцени. В Києві є й інші осередки, де плідно розвивається академічний спів. Серед таких закладів назвемо Національну академію керівних кадрів культури і мистецтв, де академічний вокал нині викладають I. Вежневець, Г. Захарченко, С. Кисла, Л. Ларікова, Ф. Мустафаєв, К. Стращенко. Академічний спів розвивається і в інших ланках музичної освіти - музичних коледжах та мистецьких школах. Відзначимо, що лише у XXI ст. програма мистецьких шкіл почала розробляти стандарти вокальних класів на основі академічного сольного співу, у радянські ж часи індивідуальний вокал як сольний у школах не викладався, а постановка голосу відбувалася відповідно до специфіки вокально-хорового мистецтва.

Окрім класичного академічного вокалу, в сучасній світовій практиці актуальними $є$ й інші. На жаль, спеціального факультету або кафедри, де вивчають академічний вокал відповідно до специфіки авангардних напрямків XX ст., які давно існують у світі, в Україні поки що немає. Ймовірно, це пов'язано з тим, що оперне виконавство в Україні орієнтовано передусім на класико-романтичний репертуар, затребуваний суспільством, а тому наразі немає необхідності відкривати спеціалізований напрям вокальної підготовки виконавців музики XX ст. Втім, у перспективі такий напрям підготовки має бути для того, щоб українська вокально-педагогічна школа продовжувала втримувати свої позиції у світі. Також немає спеціального осередку підготовки вокалістів, що виконують старовинну музику (середньовічний, ренесансний, бароковий вокал), попри те, що сьогодні в Україні є ряд виконавців та колективів, які отримали відповідну підготовку за кордоном (навчання, стажування та майстер-класи) і спеціалізуються на бароковій та ренесансній музиці. Цей напрям користується попитом у столичної публіки, чому свідоцтвом є постановка опери Г. Генделя «Ацис і Галатея» 
силами українських та зарубіжних виконавців у жовтні 2019 р., дві вистави якої пройшли з аншлагом і викликали неабиякий резонанс у мистецьких колах.

Ще два напрями вокальної підготовки - автентичний фольклорний та естрадний представлені в сучасному культурному просторі України. Особливою популярністю користується останній, він представлений на всіх ланках музичної освіти. Проте говорити про усталені традиції естрадного вокалу в українській вокально-педагогічній школі ще зарано, оскільки вони тільки формуються. Однак у перспективі естрадний спів, як і академічний, безумовно буде включено у національну вокально-педагогічну школу як їі складова частина, оскільки сучасна музика потребує таких фахівців. Розробка стандартів фахової освіти естрадних виконавців, створення потужного викладацького корпусу сприятиме академізації естрадного співу, його виходу на новий естетичний рівень. Отже, сьогодні українська вокально-педагогічна школа є у процесі трансформації відповідно до соціокультурних викликів XXI ст. Цей період можна визначити як активний відповідно типології, запропонованої М. Ржевською, і можна сказати, що початок цього століття, як і кінець попереднього, в історії української культури характеризується активним сплеском розвитку національної культури. Але рух історії передбачає не лише повторення, а й еволюцію, і тому активні процеси, що відбувалися на початку XX ст., у XXI ст. відтворюються на новому рівні, розширюючи поняття вокально-педагогічної школи, яку нині представляє не лише академічний спів, а й естрадний як такий, що активно розвивається й рухається у напряму академізації. Інші напрями вокалу представлені меншою мірою, але вони $є$ перспективою розвитку національної вокально-педагогічної школи у майбутньому.

Висновки. Українська вокально-педагогічна школа у XX ст. пройшла три етапи свого розвитку, кожен з яких тривав третину століття, у XXI ст. розпочався її четвертий етап. Перший етап ознаменовано створенням засад національної вокально-педагогічної школи на основі академічного співу у поєднанні з українськими вокально-співочими традиціями. Для другого етапу характерні стагнаційні тенденції, пов'язані з їі відірваністю від загальносвітових процесів розвитку вокального виконавства. Третій етап характеризується плюралістичністю трактування вокально-педагогічної школи, яка відтепер включає не лише академічний, а й інші види співу, актуальні у світовому культурному просторі. Четвертий етап ще не закінчено, для нього характерно продовження основних тенденцій попереднього. У співвідношенні до аналогічного періоду ХХ ст. він відрізняється більшою динамікою і на новому історичному витку повторює його культуротворчий сплеск, який заклав підвалини української вокально-педагогічної школи.

\section{Jimepamypa}

1. Антонюк В. Г. Українська вокальна школа: етнокультурологічний аспект: монографія. Київ: [б.в.], 1999. $166 \mathrm{c}$.

2.Гнидь Б. П. Історія вокального мистецтва: підручник для вищих муз. навч. закл. Київ: [б.в.], 1997. $320 \mathrm{c}$.

3.Дніпропетровська консерваторія ім. М. Глінки (1898-2008) / [під заг. ред. Т. Медведнікової]. Дніпропетровськ: АРТ-ПРЕС, 2008. 208 с.

4.Національній музичній академії України імені П. І. Чайковського 100 років / [О. Малозьомова та ін.; авт.-упоряд., керівник проекту В. Рожок; редкол.: В. Рожок та ін.]. Київ: Музична Україна, 2013. 539 с.

5. Одеська консерваторія. Славні імена, нові сторінки / Одеська державна консерваторія ім. А. В. Нежданової // Ред. М. Л. Огренич, О. М. Маркова, Л. Гінзбург, А. Станко та ін. - Одеса : ООО ГрандОдеса, 1998. - 336 с.

6. Ржевська М. До питання формування нової концепції українського музично-культурного процесу XX ст. // Мистецькі обрії’2000; Академія мистецтв України. Київ: КНВПМ «СИМВОЛ-Т», 2002. С. 64-71.

7. Ржевська М. Ю. Періодизація українського музично-культурного процесу ХХ століття як проблема динаміки культури // Українське музикознавство. Вип. 29. 2000. С. 94-102.

8. Харківський державний університет мистецтв ім. І. П. Котляревського. Рro Domo Mea: Нариси. До 90річчя 3 дня заснування Харківського державного університету мистецтв імені I. П. Котляревського // [ред. Т. Б. Вєркіна, Г. А. Абаджян, Г. Я. Ботунова та ін. Харків: Харківський державний університет мистецтв ім. І. П. Котляревського, 2007. 336 с. 